\title{
AN INVESTIGATION OF MATHEMATICS TEACHERS' EMERGENCY REMOTE TEACHING EXPERIENCES
}

\author{
Dr. Ayla ATA BARAN \\ ORCID: 0000-0003-0899-0160 \\ Faculty of Education \\ Eskisehir Osmangazi University \\ Eskisehir, TURKEY \\ Hakan BARAN \\ ORCID:0000-0002-1495-8477 \\ Graduate School of Social Sciences \\ Anadolu University \\ Eskisehir, TURKEY
}

Received: 20/11/2020 Accepted: 08/04/2021

\begin{abstract}
With the confirmation of the coronavirus epidemic as a global pandemic, and with the suspension of face-toface teaching and learning activities for all educational institutions, the concept of emergency remote teaching has come into prominence. As a process that affects a large number of students, the effective management of emergency remote teaching process has important effects on ensuring the sustainability of learning and students' well-being. It becomes an important issue to examine teachers' evaluations about their emergency remote teaching experiences. The purpose of this study was to examine the evaluations of mathematics teachers' emergency remote teaching experiences. The case study method was used and the participants consisted of 10 middle school mathematics teachers. The data were collected by semi-structured interviews. In the data analysis process content analysis method was used. As a result, it was seen that participating teachers' current understanding of the concept of distance education has influenced the way they conduct their online lessons. It was revealed that participating teachers carried out emergency remote teaching period in ways that they could transfer the face-to-face learning environment to online environment. Again, it was seen that mathematics teachers pointed to their lack of knowledge and skill about online learning.
\end{abstract}

Keywords: Emergency remote teaching, distance education, online lesson, coronavirus pandemic, middle school mathematics teacher.

\section{INTRODUCTION}

In today's digital age, distance education is becoming increasingly important due to the rapid development of communication technologies and the ease of access to information. Distance education refers to the learning process in which learners are physically, educationally and psychologically distant from other learners and learning resources without boundaries of time and space (Anderson, 2003; Moore, 1989; Moore, 1993). Distance education is an educational model that gives the learner much of the responsibility for learning and learners are expected to have self-directed and self-management learning skills (Knowles, 1975). People with different characteristics and experience can easily receive effective training with modern methods by taking advantage of distance education environments (Rovai \& Downey, 2010).

With the confirmation of the coronavirus (COVID-19) epidemic, which is effective worldwide, as a global pandemic, and with the suspension of face-to-face teaching and learning activities for all educational institutions, the concept of emergency remote teaching has come into prominence. Emergency remote teaching is about surviving in a time of crisis with all resources available, including offline and/or online (Bozkurt et al., 2020). In this regard, distance education and emergency remote teaching refer to quite different processes from each 
other. As a matter of fact, how to conceptualize emergency remote teaching and distinguish it from distance education are emphasized in the literature (e.g. Hodges, Moore, Lockee, Trust \& Bond, 2020).

Despite the differences between distance education and emergency remote teaching, teachers have a fundamental role in conducting these processes effectively. Here, as can be seen from the emphasis on "teaching", the emergency remote teaching process is mainly conducted by the teachers (Hodges et.al., 2020). However, in the emergency remote teaching process, teachers are expected to be mediators and facilitators beyond imitating face-to-face lessons in online learning environments, and enable students to take a greater role in their own learning (Yildirim, 2020). Again, considering the effects of the crisis situation in the emergency remote teaching period, the teacher role as supporting students' well-being comes into prominence (Bozkurt \& Sharma, 2020). During COVID-19 pandemic period, as the world is almost all, Turkey has also passed on quickly to the use of online classes. In Turkey, teachers' experience of emergency remote teaching period has been conducting the Education Information Network (Egitim Bilisim Agi[EBA]) online lessons. The EBA platform offers teachers the option of conducting their online lessons and exams, video lectures, course contents and access to a large number of problems. EBA online lesson, on the other hand, refers to the online classroom practice where teachers and students can come together simultaneously via EBA (http://eba.gov.tr).

When the literature on emergency remote teaching is examined, it is seen that the studies on this subject are increasing day by day. In this context, there are many studies on differences between emergency remote teaching and distance education (e.g. Bozkurt \& Sharma, 2020; Shisley, 2020; Whittle, Tiwari, Yan, \& Williams 2020). Again, it is seen that many studies are encountered to examine the reflections of the COVID-19 pandemic in the field of education (e.g. Angoletto \& Queiroz, 2020; Bozkurt, 2020; Burke \& Dempsey, 2020; Iwai, 2020; Keskin \& Ozer-Kaya, 2020; Yildirim, 2020). In these studies, it is seen that there are various discussions on the evaluation of the emergency remote teaching period. However, a limited number of studies are encountered to examine teachers' emergency remote teaching experiences (e.g. Albo, Beardsley, Martinez-Moreno, Santos \& Hernandez-Leo 2020; Talidong, 2020; Trust \& Whalen, 2020). For instance, Albo et.al. (2020) conducted a quantitative study with primary and secondary school teachers in Spain. The purpose of this study was to capture a snapshot of teachers' experiences in Spain during the emergency remote teaching. As a result of the study, it was observed that during the pandemic, teachers gained confidence in using a wide variety of technologies, however they thought that the digital divide among students and a lack of technical resources and support negatively affected the online education process. Again, Talidong (2020) conducted a quantitative study aiming to examine how Philippine teachers implemented the process of remote English language teaching among primary learners. As a result of the study, Philippine teachers are equipped with necessary preparations for emergency remote teaching in English language instruction. Likewise, they perceived emergency remote teaching as beneficial to continue the teaching and learning process. Kocoglu and Tekdal (2020) conducted a study aiming to analyze the educational activities conducted in Turkey during the pandemic. The findings revealed that, the teachers of various disciplines stated remarkable views on the education conducted during the COVID-19 pandemic.

With the suspension of face-to-face education during the COVID-19 pandemic period, 1.6 billion learners of all ages from around the globe are affected, from pre-primary to higher education. The number of students being affected by this situation in Turkey is about 25 million (UNESCO, 2020). At this point, considering the fact that emergency remote teaching is a process that affects a large number of students and the effects of effective management of this process on ensuring the sustainability of learning and students' well-being, it is an important issue to examine teachers' emergency remote teaching experiences. Again, examining teachers' experiences in this process will be valuable in terms of their contribution to the development of the EBA platform and conducting face-to-face education and distance education activities in the future. Indeed, Mulenga and Marban (2020) emphasize that without including teachers and their evaluations on the process, no paradigm change can be successfully reflected in educational settings. On the other hand, there seemed to be a lack of research focusing on mathematics teachers during this pandemic. Thus, this research is significant because it fills the gap on math teaching in distance education. In this context, the purpose of this study is to examine the evaluations of middle school mathematics teachers' emergency remote teaching experiences. In line with this general purpose of the study, the main questions explored in this study are: 
1. How do middle school mathematics teachers evaluate their emergency remote teaching experiences?

a. What meaning do middle school mathematics teachers ascribe to distance education?

b. Is there a relationship between the middle school mathematics teachers' understanding of distance education and their emergency remote teaching experiences?

c. Do middle school mathematics teachers' evaluations of their emergency remote teaching experiences differ according to the socio-economic environment in which they work?

\section{METHOD}

In this study, it was aimed to examine the evaluations of middle school mathematics teachers' emergency remote teaching experiences. Since the phenomena investigated in this study was determined as the evaluations of the middle school mathematics teachers' experiences, a holistic single case study was chosen. Case study research generally depicts and helps the researcher to analyze and understand a phenomenon related to a specific group of people (Baxter \& Jack, 2008; Bogdan \& Biklen, 2007). Additionally, a case study approach "affords researchers opportunities to explore or describe a phenomenon in context using a variety of data sources" (Baxter \& Jack, 2008, p. 544). Detailed information about the research process is given below.

\section{Participants}

The participants of the study consisted of 10 middle school mathematics teachers who were determined by criterion sampling method (Yildirim and Simsek, 2018). The selection criteria was working in schools which located in different socio-economic environments. Therefore, different socio-economic environments in the central districts of Eskisehir were determined. In this context, four of the participating teachers ( $\mathrm{Su}$, Ali, Cansu and Gorkem) works in low socio-economic environments, three of them (Ugur, Emir and Emre) works in middle socio-economic environments and three of them (Ozge, Esra and Mert) works in high socio-economic environments. Here, all participant names have been changed to pseudonyms.

\section{Data Collection and Analysis}

In this study, semi-structured interviews were conducted to examine the evaluations of mathematics teachers' emergency remote teaching experiences. In order to review the appropriateness and clarity of the interview questions, the opinions of an expert that held a doctorate degree in distance education was asked. Before collecting data for the main study, a pilot study was conducted with a voluntary middle school mathematics teacher who was not involved in the actual study in order to assess the clarity and comprehensibility of the semi-structured interview questions. As a result of the pilot study, sub-questions and the order of questions were modified and the final form of semi-structured interview questions was developed. The interviews were recorded using a voice recorder and each interview lasted nearly 30 minutes. The sample questions are presented in Table 1.

Table 1. Semi-structured interview sample questions

Sample questions

- What does the concept of distance education mean?

- What are the advantages/disadvantages of distance education compared to face-to-face education?

- What are your views on the use of digital technologies in distance education?

- How do you conduct your online lessons?

- Which technology and materials do you use in your online lessons?

How do you evaluate your effectiveness in conducting your online lessons? 
Semi-structured interview data were analysed through content analysis method. In content analysis, the data are gathered around similar concepts and themes, then interpreted in a way that the reader can understand (Creswell, 2014). In this context, firstly, codes were determined through reading the transcripts several times. Then, these codes were combined under certain categories and themes, then finalized as a result of the reliability study. During the reliability study, the researcher and an expert that held a doctorate degree in distance education studied independently and decided on the suitability of the codes and categories. In this context, the percentage of compliance between raters was examined by using the formula as $[\mathrm{P}$ $=[\mathrm{Na} /(\mathrm{Na}+\mathrm{Nd})] \times$ 100] (P: Percentage of Compliance, Na: Number of agreement, Nd: Number of disagreement) (Miles \& Hubermen, 1994). The reliability between coders was calculated as $90 \%$. Miles and Huberman (1994) suggest that an inter-rater reliability of $80 \%$ agreement between coders on $95 \%$ of the codes is sufficient agreement among multiple coders. Therefore, this value showed that the scores are consistent with each other. On the other hand, regarding the situations in which the researcher and the field expert had disagreement, an assist professor in the field of distance education was consulted and a consensus was reached. Finally, at the last step of the analysis the categories are interpreted in line with the purpose of the study.

\section{FINDINGS}

Regarding the participants' evaluations about their emergency remote teaching experiences, five themes were determined as "the concept of distance education", "using digital technologies in distance education", "EBA online lessons", "shortcomings of EBA online lessons" and "expectations". In the analysis of the theme of the concept of distance education, two categories were identified. These categories consisted of: i) lessons in online environments and ii) emergency remote teaching. Three categories were identified across the interviews about use of digital technologies in distance education. These categories consisted of: $i)$ use of the internet, ii) use of social media and iii) use of the video. In the analysis of the theme of EBA online lessons, two categories were identified. These categories included: i) use of technology and material, ii) interactions between learner and teacher. Under the theme of shortcomings of EBA online lessons, three categories were identified as i) lack of knowledge about online learning, ii) lack of interaction and iii) lack of technical resources. Lastly, the theme of expectations consisted of 'organizing in-service teacher trainings' category.

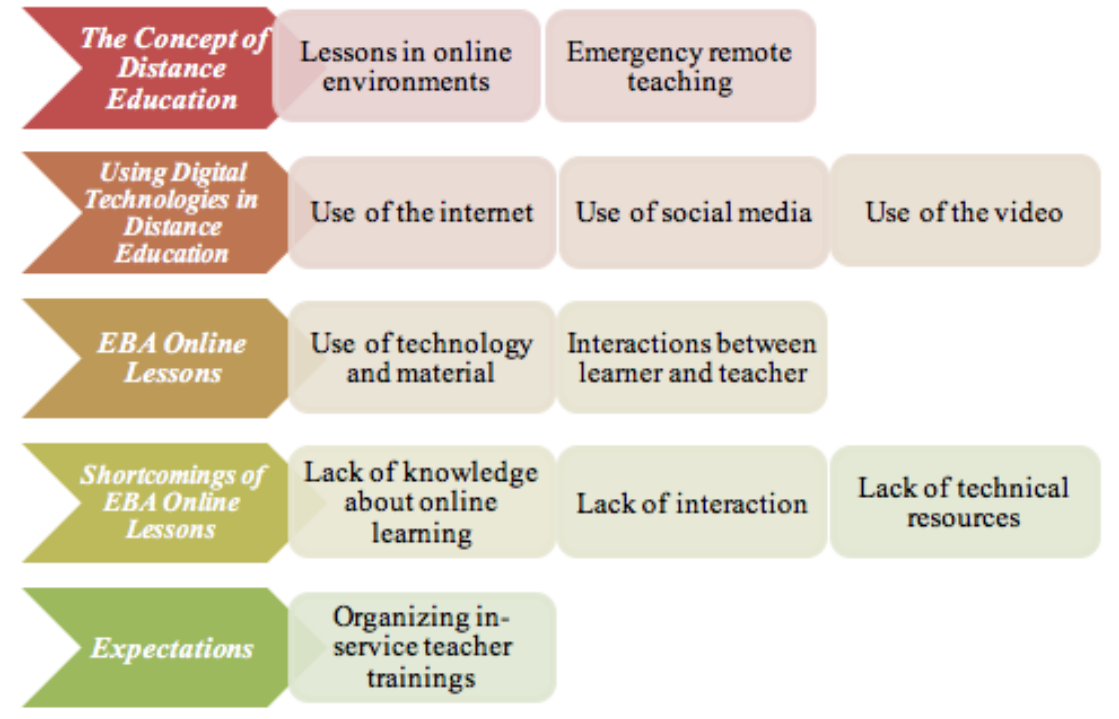

Figure 1. Themes and categories related to emergency remote teaching experiences 


\section{The Concept of Distance Education}

In semi-structured interviews, the question of "What does the concept of distance education mean?" was directed first. The answers obtained here showed that regardless of the socio-economic environment in which they work, most of the participants (seven out of 10 participants) thought that the expression of 'distance' refers only to physical distance between teacher and students. For instance, Emre stated that “... the environment that allows teachers to transfer knowledge without being in the same physical environment with students" and Mert stated that "Distance education means digital learning environment". On the other hand, it was remarkable that the remaining three participants (Ugur, Esra and Gorkem) pointed to the meaning of emergency remote teaching. The views of the participants, which clearly respond to the emphasis on being an obligation and on the effort to keep education alive in crisis, are presented below.

$$
\begin{aligned}
& \text { Ugur: ... a teaching process that is a compensation for the lack of face-to-face teaching. } \\
& \text { Esra: Distance education is designed to compensate for face-to-face education thus it prevents students } \\
& \text { to take a dislike to school or lessons. } \\
& \text { Gorkem: ... trying to teach remotely to students that we cannot meet face-to-face. }
\end{aligned}
$$

Thus, it reflected that the meaning participants ascribe to distance education was transferring of face-to-face learning to the online environment. Here, considering that the emergency remote teaching process is the first online learning experience of the participants, it can be thought that this situation affects the meaning they ascribe to distance education. On the other hand, all the participants pointed to the importance of distance education in today's digital age. They agree that distance education is gaining increasing importance in every aspect of life.

Following their views regarding what the concept of distance education means, participants' views about the advantages and/or disadvantages of online learning compared to face-to-face learning were questioned. In this context, all of the participants evaluated the advantages and/or disadvantages of distance education depending on the emergency remote teaching process which they experienced during the COVID-19 pandemic. They thought that the most obvious advantage of emergency remote teaching is the flexibility of time and space for learners. In addition, Emir pointed out the advantage of diversity of digital content. $\mathrm{He}$ stated that "Distance education provides access to different digital contents, multiple media, visual and audio" and reflected his knowledge on this subject. Again, Cansu, who has a student from the disadvantaged student group in her class, stated the advantage of providing important facilities for disadvantaged students. She said that "My disabled student participated in online lessons very comfortably during COVID-19 outbreak and this was a great advantage for her." Another participant, Ozge, expressed the advantage of supporting learners' academic performance increase. She said that "Introverted students can make incredible progress in distance education process, I have observed it in my own online lessons". On the other hand, half of the participants (Ugur, Cansu, Ali, Gorkem and Su), mainly working in low socio-economic environments, considered lack of technical resources to hamper in education, and nearly half of the participants (six out of 10 participants) considered weakness of interaction between teacher and students in online learning environments as a significant disadvantage for distance education. Some sample views are presented below.

Gorkem: There are students who don't have the technology required for distance education, there are students who don't have internet. That's why not being able to reach every student is a major disadvantage.

Cansu: Interaction with students is very important. Not being able to see the gestures and movements of the students during the distance education process and not being able to get feedback creates hesitations about whether the subject is understood or not. I think it is a big disadvantage.

\section{Using Digital Technologies in Distance Education}

In order to examine participants' views about the use of digital technologies in distance education, firstly, participants' views about the use of the internet were questioned. Here, it was seen that regardless of the socio-economic environment in which they work, most of the participants (eight out of 10 participants) stated that they use internet for the purpose of accessing written contents such as z books, mathematical 
problems and learning outcomes tests in the EBA platform. For instance, one of these participants stated that "I access z books via the internet. Because, I usually prefer using books with video solutions" (Esra). Another participant stated that "I generally use internet to find different types of problems and to see the experiences of other teachers" (Emre). Thus, it clearly reflected the participants' use of internet to access different types of written content. On the other hand, regarding the use of the internet in mathematics teaching, four participants (Ugur, Ali, Cansu and Mert) mentioned the use of various educational software in order to generate technology-supported lessons. For instance, one of these participants stated that "We know that some mathematics subjects can be taught more easily through educational software" (Ali). Another participant stated that "I think that the use of internet, in a sense, educational software is very useful especially in subjects such as geometry and three-dimensional objects" (Ugur).

In order to examine participants' views about the use of digital technologies in distance education, secondly, participants' views about the use of educational social media were questioned. It was seen that, all of the participants stated that they did not know any educational social media platforms (e.g. Edmodo, Edcanvas) and did not use any of them. Thus, they interpreted the use of educational social media in distance education as the educational use of social media platforms (such as Facebook, WhatsApp, YouTube). In this context, two of the participants (Ugur and Ali) thought that social networks does not support the development of mathematical knowledge and skills. On the other hand, it was seen that rest of the participants' use of social networks was limited to WhatsApp platform. They stated that they use this platform to solve mathematical problems that students have difficulty and to share various documents with students. Some sample views are presented below.

Cansu: I think social networks are useful. For instance, I send math videos to my students via social network. Again, I can send voice recordings to answer students' questions.

Ozge:... For instance, students take a photo of a problem and send it on WhatsApp, and I solve it and send back. When (s)he doesn't understand the solution, I press the voice recording button and explain it. An incredibly useful application.

In order to examine participants' views about the use of digital technologies in distance education, lastly, participants' views about the use of video in distance education were questioned. Here, it was seen that all of the participants regarded the use of educational videos as video lectures that can be accessed from various platforms (such as Education Information Network, YouTube). In this context, the participants thought that video lectures are digital contents that help students to understand the mathematical subjects and/ or mathematical problems that they have difficulty to understand. For instance, Esra stated that "Students can watch the video lectures of any teacher on math subjects they do not understand". Similarly, Emre stated that "Students can watch the video lectures to make up their shortages in math subjects or problems" and these expressions reflected the participants' points of views about the use of videos in distance education.

\section{EBA Online Lessons}

In order to examine participants' evaluations about their emergency remote teaching experiences, the question of "How do you conduct your EBA online lessons?" was directed first. In this context, the participants pointed to their effort to transfer the face-to-face learning environment to online environment in EBA online lessons. Below, the explanations of Cansu and Esra about how they conducted their online lessons are presented as example.

Canan: ... I screen shared the mathematics textbook. I conducted my online lessons based on the textbook and solved the problems in the textbook. I have also download some documents about mathematical problems and shared my screen. I wanted students to solve the problems. Then, the students who solved the problems explained how they solved it.

Esra: I have accessed the $z$ books of several publications. I shared my screen like using a smart board at school. I explained the subject first and then we solved problems. When you press the solution button in $z$ books, the solution of the problem appears on the screen, so I shared the solution. 
Additionally, the participants stated that they could not adopt any online learning teaching strategies. As a matter of fact, expressions such as "I try to conduct my online lessons similar to the lessons I taught in the classroom (Emre)" and "Online lessons should have been different from face-to-face education, but I could not do something different (Ugur)" clearly reflect this situation.

On the other hand, online lesson materials used by the participants were mainly mathematics textbooks, lecture slides, video recordings (EBA videos), z books and screen sharing technology. However, one of the participants, Ozge stated that she used the Kahoot application as a Web 2.0 tool, while another participant Gorkem stated that she prepared lecture videos on YouTube. Some sample views are presented below.

Emir: I share the videos and content of EBA. I am trying to solve learning objectives tests/problems in EBA platform. I can say that I chose using this platform because it was easy.

Cansu: I always get my students watch EBA videos in face-to-face education, and I think EBA videos are useful in the distance education process, too.

Ozge: I wondered how to make online lessons more enjoyable and how the students participate in online lessons. As an alternative, I used the Kahoot app.

Following questioning how the participants conducted their EBA online lessons, their evaluations regarding the provision of interaction (interactions between learner-teacher and learner-learner) were questioned. Here, it was observed that the participants tried to increase learner-teacher interactions in online lessons by providing instructional communication or instructional support. That is, the participants stated that they asked questions about the mathematics subject or encouraged students to ask questions about the subject in order to interact with the students. For instance, the following expressions reflected the participants' efforts to increase learner-teacher interactions, "I generally provide interaction by opening the microphone of the student so that s(he) can answer my question" (Ugur) and "I want students to ask questions, that is, to talk about things they do not understand" (Ali).

On the other hand, almost all of the participants (nine out of 10 participants) believed that they could not provide learner-learner interactions in their online lessons. These participants stated that in the emergency remote teaching period, students' microphones and cameras were turned off in online lessons, and this limitation restricted the interaction of students with each other. Accordingly, the participants stated that in their online lessons students were quite passive and that they mainly used the method of direct instruction. For instance, Emre stated that "In truth, the students did not interact much with each other, they just listened to me". Similarly Esra stated that "I did not allow the students to interact with each other. They did not share any knowledge or make screen sharing". On the other hand, the following expression of Ozge reflected her effort to provide learner-learner interactions, "I asked questions such as What do you think?, What do you think about your friend's thinking?, Do you agree or disagree with your friend?".

\section{Shortcomings of EBA Online Lessons}

Following their views about EBA online lessons, the participants were asked to make a self-assessment of their effectiveness in conducting the EBA online lessons. In this context, all of the participants stated that in emergency remote teaching period, they worked to support students' understanding of mathematics subjects, as such in the face-to-face learning. However they found themselves partially sufficient to conduct online lessons effectively. In this context, all the participants pointed to their lack of knowledge and skill to use online learning. Therefore, the participants emphasized their need for professional development about use of digital technology and designing online lesson materials for distance mathematics education. Some sample views are presented below.

Su: I feel very lacking in how to teach mathematics more effectively in distance education.

Cansu: I have to make progress in using the internet effectively, designing digital mathematical content, designing online lessons and making instructional videos.

Ugur: How can I design a course material that will make students more active? It is important that I should make progress in this regard. 
On the other hand, the participants, especially working in low socio-economic environment, emphasized students' lack of access to a computer/laptop or not having internet connection. For instance, Gorkem stated that "I did my best, but I think it wasn't very effective. Most of the students could not participate in the online lessons due to lack of access to a computer. On the other hand, I don't know to what extent did the students participate in and follow the lesson". Besides, nearly half of the participants (six out of 10 participants) emphasized lack of interactions between learner-teacher and learner-learner in online lessons. They drew attention to the negative effects of lack of interaction on giving feedback to students and on conducting online mathematics lessons effectively. For instance, Cansu stated that "I don't think I am very effective in EBA online lessons. Because interaction is really important in math classes. I think that the inability to interact with the students significantly affected the effectiveness of the process".

\section{Expectations}

When their expectations regarding professional development about distance education were questioned, all of the participants thought that the emergency remote teaching period was an introduction to the widespread use of distance education. Accordingly, they emphasized that professional development in distance education has become a fundamental requirement. Thus, they expressed their expectations of in-service trainings which will be organized by the Ministry of National Education. In this context, depending on their lack of knowledge and skill to use online learning, participants expressed their expectations of in-service trainings about use of digital technologies and online lesson materials. Here, it was also seen that the participants, who emphasize lack of interactions between learner-teacher and learner-learner in online lessons, agreed that mathematics can be thought more effectively in face-to-face learning environments. Accordingly, these participants expressed their need for online learning environments that make students active participants of their learning process. Some sample views are presented below.

Emre: We need an online learning environment and e-learning contents that will make students more active.

Cansu: I would like to design digital mathematics contents, design lectures and make math videos by using digital technologies.

Ali: Trainings about how to plan interactive online lessons to ensure student participation can be organized.

Ugur: I think that a training about how to design or implement online lesson materials that will motivate students and enable them to participate in the lesson will contribute to my professional development.

\section{DISCUSSION AND CONCLUSION}

Considering the emergency remote teaching period that was rapidly implemented in Turkey and all around the world during the COVID-19 outbreak and the role of teachers in carrying out this process effectively, in this study it was aimed to examine the evaluations of middle school mathematics teachers' emergency remote teaching experiences. The participants of this study was ten middle school mathematics teachers who was working in schools located in different socio-economic environments. As a result of the semi-structured interviews, it was seen that the meaning participating mathematics teachers ascribe to the concept of distance education was transferring of traditional classroom/face-to-face learning environment to the online environment. Besides, the participating mathematics teachers' understanding of using digital technologies in distance education was limited to access different types of written content via the internet or using social media platforms (e.g. WhatsApp and YouTube) for educational purposes or using video lectures that can be accessed from platforms such as Education Information Network, YouTube. As it is known, "distance" expression in the concept of distance education emphasizes physical, interactional and psychological distance and the expression 'remote' in the concept of emergency remote teaching emphasizes just physical distance (Bozkurt, 2020). Therefore, it can be said that participating mathematics teachers have a lack of knowledge about the concept of distance education. Here, it may be suggested to provide teachers with education about what distance education is and in what cases and how it should be applied. 
Another result of the study was that regardless of the socio-economic environment in which they work, the participating mathematics teachers carried out emergency remote teaching period in ways that they could transfer the face-to-face learning environment to online environment. The educational activities of the participating mathematics teachers were mainly screen sharing mathematics textbooks or lecture slides, using z books, getting students to watch EBA videos or using video lectures. Thus, it can be said that participating mathematics teachers tried to replicate their face-to-face teaching strategies in online lessons and that their current understanding of the concept of distance education has influenced the way they conduct their online lessons. Considering that, emergency remote teaching differs from conventional distance education: being suddenly, unreadily and forcefully implemented (Hodges et.al., 2020), it may be usual that participating mathematics teachers made an effort to transfer their face-to-face lessons to the online environment during the pandemic period. However, it has been understood that in order for the distance education systems to be applied in situations such as the COVID-19 pandemic, teachers' knowledge and skill to use online learning should be improved. As a matter of fact, it was observed that participating mathematics teachers felt themselves partially sufficient to achieve the educational objectives by carrying out the emergency remote teaching process effectively and efficiently. They pointed to their lack of knowledge and skills to use online learning. Mailizar, Almanthari, Maulina and Bruce (2020) revealed a similar result that the top e-learning barrier regarding teachers as lack of knowledge and skills to use e-learning and their lack of confidence. Similarly, Trust and Whalen (2020) revealed that the biggest challenges teacher face during emergency remote teaching process was lack of knowledge about online/ remote teaching strategies and tools.

Regarding their evaluations about shortcomings of online lessons, participating teachers also pointed to lack of interactions between learner-teacher and learner-learner in online lessons. These results are consistent with earlier research (e.g. Tumen-Akyildiz, 2020; Hebebci, Bertiz \& Alan, 2020; Karakaya, Arik, Cimen \& Yilmaz, 2020). For instance, Hebebci, Bertiz and Alan (2020) revealed that the most important problem that teachers draw attention regarding distance education practices during COVID-19 pandemic is the lack of interaction. At this point it was also remarkable that because of lack of interactions between learnerteacher and learner-learner in online lessons, participating mathematics teachers used the method of direct instruction. Accordingly, they emphasized the importance of online learning environments that make students active participants of their mathematics learning process. Kocoglu and Tekdal (2020) also revealed a similar result in the study in which they analyze remote teaching activities. In this study it was observed that teachers used teacher-centered instruction method during remote teaching process. As is known, the online learning process should be designed in a way that students are more active, learner-centered and focused on supporting the knowledge and skills needed in the digital age (Bates, 2016). In other words, quality teaching designs in which learning objectives are clearly defined, educational content is carefully structured and innovative teaching methods gain importance. This requires teachers to be equipped with digital and pedagogical skills to teach remotely or online learning (LaBonte, 2020; UNICEF, 2020). In this regard, supporting the professional development of mathematics teachers about online learning becomes an issue that should be emphasized. As a consequence, it can be suggested to develop teacher training programs about how to design qulity online teaching and learning with technology. Thereby, teachers should be provided with the opportunity to develop knowledge and skills so that they are prepared to teach with technology in different formats or situations including online, remote or blended settings.

Finally, in this research it was seen that participating mathematics teachers, especially working in low socioeconomic environments, mentioned lack of students' technical resources as a significant shortcoming of emergency remote teaching process. This result is consistent with earlier research results as one of the top e-learning barrier regarding students as lack of access to devices and internet connection for e-learning purposes (e.g. Albo et.al. 2020; Mailizar, Almanthari, Maulina \& Bruce, 2020; Trust \& Whalen 2020). Based on this result, it can be suggested to investigate challenges that mathematics teachers with students in low-income communities face during emergency remote teaching period. For instance, studies can be conducted to investigate mathematics teachers' use of technology and if there is a limitation in their use of technology due to access issues. In addition, similar studies can be conducted with students to examine their evaluations of online mathematics teaching. 


\section{BIODATA and CONTACT ADDRESSES of AUTHORS}

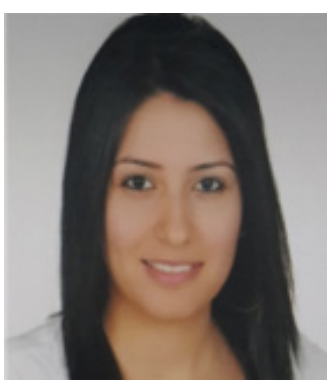

r. Ayla ATA BARAN is an assistant professor at the Department of Mathematics Education, Faculty of Education, Eskisehir Osmangazi University. Dr. Ata-Baran gained her Ph.D. in Mathematics Education at February, 2019. Her academic interest areas are mathematical communication, the language of mathematics, mathematical literacy and mathematical modeling. She has over than 10 journal articles published in national and international indexes and three international book chapters. She also has lots of presentations at national and international meetings.

\section{Ayla ATA BARAN}

Department of Mathematics Education, Faculty of Education

Address: Eskisehir Osmangazi University, 26040, Eskisehir, Turkey

Phone: +90 2222393750

E-mail: abaran@ogu.edu.tr

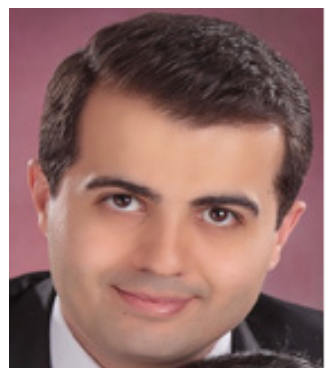

Hakan BARAN works as a mathematics teacher at Melahat Unugur Middle School, Ministry of National Education. He gained his Bachelor in Educational Administration, Inspection, Economics and Planning at Eskisehir Osmangazi University. His academic interest areas are assessment and evaluation, distance education, online learning and learning design. He has three journal articles published in national and international indexes. He also has lots of presentations at national and international meetings.

Hakan BARAN

Department of Distance Education, Graduate School of Social Sciences

Address: Anadolu University, 26470, Eskisehir, Turkey

Phone: +90 2223350580

E-mail: hakanbaran@anadolu.edu.tr

\section{REFERENCES}

Albo L., Beardsley M., Martinez-Moreno J., Santos P., \& Hernandez-Leo, D. (2020). Emergency Remote Teaching: Capturing Teacher Experiences in Spain with SELFIE. In: Alario-Hoyos C., RodriguezTriana M., Scheffel M., Arnedillo-Sanchez I., Dennerlein S. (eds) Addressing Global Challenges and Quality Education. EC-TEL 2020. Lecture Notes in Computer Science, vol 12315. Springer, Cham.

Anderson, T. (2003). Modes of interaction in distance education: Recent developments and research questions. In M. Moore (Ed.), Handbook of Distance Education, 129-144. Mahwah, NJ.: Erlbaum.

Angoletto, R., \& Queiroz, V. C. (2020). COVID-19 and the challenges in education. The Centro de Estudos Sociedade e Tecnologia (CEST), 5(2).

Bates A. W. (2014). Teaching in a digital age: Guidelines for designing teaching and learning. Vancouver BC: Tony Bates Associates Ltd.

Baxter, P., \& Jack, S. (2008). Qualitative case study methodology: Study design and implementation for novice researchers. The Qualitative Report, 13(4), 544-559.

Bogdan, R., \& Biklen, S. (2007). Qualitative research for education (5th ed.). Boston: Allyn \& Bacon.

Bozkurt, A. (2020). Koronavirus (Covid-19) pandemi sureci ve pandemi sonrasi dunyada egitime yonelik degerlendirmeler: Yeni normal ve yeni egitim paradigmasi. AUAd, 6(3), 112-142. 
Bozkurt, A., \& Sharma, R. C. (2020). Emergency remote teaching in a time of global crisis due to CoronaVirus pandemic. Asian Journal of Distance Education, 15(1), i-vi.

Bozkurt, A., Jung, I., Xiao, J., Vladimirschi, V., Schuwer, R., Egorov, G., ... Paskevicius, M. (2020). A global outlook to the interruption of education due to COVID-19 Pandemic: Navigating in a time of uncertainty and crisis. Asian Journal of Distance Education, 15(1), 1-126.

Burke, J., \& Dempsey, M. (2020). COVID-19 Practice in primary schools in Ireland report. National University of Ireland Maynooth, Ireland. https:/www.into.ie/app/uploads/2020/04/COVID-19Practice-in-Primary-Schools-Report- 1.pdf.

Creswell, J. W. (2014). Research design: Qualitative, quantitative and mixed methods approaches (4th ed.). London: Sage Publications Ltd.

Egitim Bilisim Agi (EBA). (October, 2020). EBA'dan Canli Sinif. Retrieved October 20, 2020 from http:// eba.gov.tr.

Hebebci, M. T., Bertiz, Y., \& Alan, S. (2020). Investigation of views of students and teachers on distance education practices during the Coronavirus (COVID-19) Pandemic. International Journal of Technology in Education and Science (IJTES), 4(4), 267-282.

Hodges, C., Moore, S., Lockee, B., Trust, T., \& Bond, A. (2020). The difference between emergency remote teaching and online learning. Educause Review. https:/er.educause.edu/articles/2020/3/ thedifference-between-emergency-remote- teaching-and-online-learning.

Iwai, Y. (2020). Online Learning during the COVID-19 Pandemic: What do we gain and what do we lose when classrooms go virtual?, Scientific American.

Karakaya, F., Arik, S., Cimen, O., \& Yilmaz, M. (2020). Investigation of the views of biology teachers on distance education during the COVID-19 pandemic. Journal of Education in Science, Environment and Health (JESEH), 6(4), 246-258.

Keskin, M., \& Ozer-Kaya, D. (2020). Evaluation of students' feedbacks on web-based distance education in the COVID-19 process. Izmir Katip Celebi Universitesi Saglik Bilimleri Fakultesi Dergisi, 5(2), 59-67.

Kocoglu, E., \& Tekdal, D. (2020). Analysis of education activities conducted during COVID-19 pandemic. Educational Research and Reviews, 15(9), 536-543.

Knowles, M. S. (1975). Self-directed learning: A guide for learners and teachers. New York: Association Press.

LaBonte, R. (2020). Emergency Remote Teaching: Resources, Tools, and Ideas. Retrieved October 20, 2020 from https://canelearn.net/emergency-remote-teaching/

Mailizar, Almanthari, A., Maulina, S., \& Bruce, S. (2020). Secondary school mathematics teachers' views on e-learning implementation barriers during the Covid-19 pandemic: The case of Indonesia. Eurasia Journal of Mathematics, Science and Technology Education, 16(7).

Miles, M., \& Huberman, A. (1994). Qualitative data analysis (2 ${ }^{\text {nd }}$ ed). Thousand Oaks, CA: Sage.

Moore, M. G. (1989). Three types of interaction. American Journal of Distance Education, 3(2), 1-6.

Moore, M. G. (1993). Theory of transactional distance. In D. Keegan (Ed.), Theoretical principles of distance education, 22-38. New York: Routledge.

Mulenga, E. M., \& Marbán, J. M. (2020). Is COVID-19 the gateway for digital learning in mathematics education? Contemporary Educational Technology, 12(2).

Rovai, A. P., \& Downey, J. R. (2010). Why some distance education programs fail while others succeed in a global environment. The Internet and Higher Education, 13(3), 141-147.

Shisley, S. (2020). Emergency remote learning compared to online learning. Learning Solutions. https:// learningsolutionsmag.com/articles/emergency-remote-learning-compared-to-online-learning

Talidong, K. J. (2020). Implementation of emergency remote teaching (ERT) among Philippine teachers in Xi'an, China. Asian Journal of Distance Education, 15(1), 196-201. 
Trust, T., \& Whalen, J. (2020). Should teachers be trained in emergency remote teaching? Lessons learned from the Covid-19 pandemic. Journal of Technology and Teacher Education, 28(2), 189-199.

Tumen-Akyildiz, S. (2020). College students' views on the pandemic distance education: A focus group discussion. International Journal of Technology in Education and Science (IJTES), 4(4), 322-334.

United Nations Educational, Scientific and Cultural Organization (UNESCO). (2020). School closures caused by Coronavirus (Covid-19). UNESCO. https:/en.unesco.org/covid19/educationresponse

United Nations International Children's Emergency Fund (UNICEF). (2020). Teachers: Leading in crisis, reimagining the future. https://www.unicef.org/press-releases/teachers-leading-crisis-reimaginingfuture

Whittle, C., Tiwari, S., Yan, S., \& Williams, J. (2020). Emergency remote teaching environment: A conceptual framework for responsive online teaching in crises. Information and Learning Sciences, 121(5/6), 311-319.

Yildirim, K. (2020). Lessons from an exceptional distance education experience. Alanyazin, 1(1), 7-15. 